December 2019

\title{
Understanding Diversity and Intellectual Freedom as \#corevalues
}

Deborah Hicks

San Jose State University, deborah.hicks@sjsu.edu

Follow this and additional works at: https://scholarworks.sjsu.edu/ischoolsrj

Part of the Archival Science Commons, Cataloging and Metadata Commons, Collection Development and Management Commons, Information Literacy Commons, Museum Studies Commons, Scholarly Communication Commons, and the Scholarly Publishing Commons

\section{Acknowledgements}

a

\section{Recommended Citation}

Hicks, D. (2019). Understanding Diversity and Intellectual Freedom as \#corevalues. School of Information Student Research Journal, 9(2). https://doi.org/10.31979/2575-2499.090202 Retrieved from https://scholarworks.sjsu.edu/ischoolsrj/vol9/iss2/2

This article is brought to you by the open access Journals at SJSU ScholarWorks. It has been accepted for inclusion in School of Information Student Research Journal by an authorized administrator of SJSU ScholarWorks. For more information, please contact scholarworks@sjsu.edu. 


\title{
Understanding Diversity and Intellectual Freedom as \#corevalues
}

\section{Keywords}

Twitter, diversity, intellectual freedom, equity, American Library Association, ALA, inclusive, professional practices, LIS professionals, librarianship, public libraries, values, community

\section{Acknowledgements}

\section{a}

\begin{abstract}
About Author
Dr. Deborah Hicks, assistant professor at the San José State University School of Information, was recently awarded $\$ 5,000$ through the Central Research, Scholarship and Creative Activity Grant Program for her project "Debating Diversity; How Twitter Facilitates Professional Discussions." Hicks, whose research has been published in Library Quarterly, Library Trends and other LIS journals, as well as in her book, Technology and Professional Identity of Librarians: The Making of the Cybrarian (2014), received her PhD in Educational Administration and Leadership from the University of Alberta, her MLIS from Dalhousie University, her MA from York University, and her BA from the University of King's College. She currently teaches INFO 204 Information Professions in the Master of Library and Information Science program at the iSchool.
\end{abstract}


Librarianship has a long history of grappling with its stated commitment to diversity. Although the American Library Association's (ALA) first policy on diversity, "Equity At Issue," was only drafted in 1986 (Figueroa, 2018), efforts to make the profession more diverse and to create more inclusive spaces for staff and clients have been around much longer (see for example, the history of the Black Caucus of the American Library Association, 2018). Currently, there is little doubt that librarianship is committed to diversity as a core value. This commitment is made evident through the Spectrum Scholarship Program aimed at improving diversity among leaders in the field, recruitment efforts to improve the diversity of the profession's demographics, professional standards directed towards increasing cultural competencies among information professionals, and countless programs and services aimed at meeting the information needs of underrepresented members of our communities. However, there are recurring questions about the success of such measures. Critics have focused on how professional practices have reinforced racism historically (Schlesselman-Tarango, 2016) and in contemporary librarianship (Alabi, 2015).

Many of these critiques highlight a tension within librarianship over its core values of diversity and intellectual freedom. Gibson, Chancellor, Cooke, Dahlen, and Lee (2017), for instance, question whether librarianship can be both neutral and still meet the needs of people of color. In other words, they are asking if librarianship can uphold its values of intellectual freedom and diversity at the same time. Recently, Twitter has served as a platform for librarians to publicly debate the profession's core values, particularly diversity and intellectual freedom. These debates not only echoed the tensions identified in the library and information science literature, but they have also resulted in changes to professional approaches to diversity issues.

An excellent example of how these tensions manifest in our professional discourses is the recent debate over the ALA's revision of "Meeting Rooms: An Interpretation of the Library Bill of Rights." In February 2018, a working group of the ALA's Intellectual Freedom Committee (IFC) was tasked with reviewing the association's intellectual freedom documents. After extended discussion among members of the IFC and invitations for comment from the ALA membership, a draft of the revised interpretation was presented at the ALA Council Forum in June 2018. The final approved revision included hate groups among those who could use library meeting spaces:

Public libraries are bound by the First Amendment and the associated law governing access to a designated public forum. A publicly funded library is not obligated to provide meeting room space to the public, but if it chooses to do so, it cannot discriminate or deny access based upon the viewpoint of the speaker or the content of the speaker's speech. This encompasses religious, political, and hate speech. If a library allows charities, non-profits, and sports organizations to discuss their activities in library meeting rooms, then the library cannot exclude religious, social, civic, partisan political, or hate groups from discussing 
their activities in the same facilities. Allowing religious groups to use the library's meeting rooms does not constitute a breach of the First Amendment's Establishment Clause (LeRue, 2018, para. 33, emphasis added).

Although there was some limited debate about the inclusion of hate groups during the Council Forum (see LeRue, 2018 for a full timeline of events), the majority of the public debate around this revision occurred on Twitter after it had been approved, with the conversations coalescing around the hashtags \#NoHateALA and \#IStandWithALA. In August 2018, in response to fierce online opposition, the ALA Council voted to rescind the revised interpretation and sent the draft back to the IFC ("ALA Council Rescinds," 2018).

A more recent example of the tensions at the center of our core values was the Toronto Public Library's (TPL) decision to rent theater space to Megan Murphy - a writer and speaker well-known in Canada for speaking out against the rights of transgender women. The event drew protesters (Winsa, 2019), a change.org petition to cancel the event (Leung, 2019), and garnered international attention ("Megan Murphy," 2019). Many librarians and library associations applauded the decision to continue the event, arguing it promoted intellectual freedom and free expression (see, for example, CFLA-FCAB, 2019). However, this support was contested by organizations such as the Toronto Public Library Workers Union (2019), the York University Faculty Association's librarians and archivists (krisjoseph, 2019), and groups of unaffiliated librarians (Bird, n.d.), who wrote open letters condemning the decision to continue the event. Not surprisingly, the event generated its own hashtag on Twitter (\#TakeBackTPL).

These debates highlight how librarians are currently attempting to collectively define and understand their core values. The different outcomes of these events strongly suggest that there is no immediate end to these debates or tensions. They reflect larger societal tensions and have been at the core of our professional work for a long time. Elmborg (2016) describes how the controversial nature of the profession's core values has been around since their initial articulation in 2000. Many of the critiques he outlines are grounded in how the core values have been articulated by the American Library Association, specifically that the values are grounded in a neo-liberal rhetoric that focuses on the economy and job growth. Others have argued the ALA's definitions are too simplistic. Mathuews (2016), for example, says the ALA's various statements of diversity, as found in the Library Bill of Rights (1996) and the Code of Ethics (2008), focus on diversity through the lens of representation, which only addresses one part of a much more complex issue. Dresang (2006) suggests that the seemingly clear-cut value of intellectual freedom, namely the "freedom to think or believe what one will, freedom to express one's thoughts and beliefs in unrestricted manners and means, and freedom to access information and ideas regardless of the content or viewpoints of the author(s) or the age, background, or beliefs of the receiver," (p. 169) is not so clear-cut in practice, due in part to legal interpretations and public opinion. 
These events also highlight the power of Twitter as a platform for professional discussions. Traditionally, librarians have been published in magazines and journals and gather at professional conferences to discuss, debate, and find consensus around core values, controversial topics, and the future directions of the field. Social media platforms, such as Twitter, have provided additional ways for librarians to explore and consider these issues. What distinguishes social media communication is its fast pace and the opportunity for open dialogue among geographically dispersed people. In addition, the use of affordances such as hashtags mean that ideas and discussions can spread organically throughout a community (Saxton, Niyirora, Guo, \& Waters, 2015). There is a clear expectation that librarians should be using Twitter for connecting with other librarians and keeping "tabs on developing issues" (McLaughlin, 2018, p. 57); however, research into how librarians use social media is limited. Although the \#critlib Twitter community, an activist community within librarianship focused on social justice issues, has received some attention within the literature (Almeida, 2018; Coombs \& Rhinesmith, 2018), most research is focused on how libraries are using Twitter to interact with clients (Shiri and Rathi, 2013). Research focusing on allied professions has demonstrated that Twitter, in particular, provides an online space for community development and relationship building among professionals (Gruzd, Takhteyev, \& Wellman, 2011).

I will be examining both the current debates surrounding the profession's core values and how librarians use Twitter to connect in my grant-funded research project: "Debating Diversity: How Twitter Facilitates Professional Discussions." My earlier research into librarians' professional identity highlighted the important role upholding the values of librarianship plays in the profession's identity. In fact, upholding the values of librarianship has even been described as a "professional obligation" (Selby, 2012, p. 38). In my earlier data set, privacy, access to information, and freedom of expression were the most frequently mentioned values. For some librarians, these professional values even took precedence over personal values, which one of my public librarian participants described in the following way: "Do I really want little Janie coming to storytime and walking past a computer with hardcore pornography on it? No I don't. And so as a person, I don't want-I don't actually want that unfettered access to information. As a librarian I do." This work will build on my past research by examining the events surrounding the ALA's revision of "Meeting Rooms: An Interpretation of the Library Bill of Rights" and its subsequent debates on Twitter. This approach was chosen because the depth of data required to complete the study allows the complexity surrounding the case to be captured, namely the interactions, communications, relationships, and practices which occurred during the event (Mills, Durepos \& Wiebe, 2010). It is particularly suited to the study of professional communities (Hamilton \& Corbett-Whittier, 2013). This project will address two critical gaps within LIS. First, it will provide an increased awareness of how librarians understand the core values of diversity and intellectual freedom. By incorporating empirical evidence from practitioners, this project will bring added nuance to the discussions that already surround these values in the LIS literature. This will not only add additional clarity to this specific debate, but also 
to how debates within librarianship connect to and reflect similar conversations occurring in higher education (Rawlinson, 2019), the tech industry (Moorhead, 2019), and other allied professions and sectors. Secondly, it will also generate an understanding of how librarians use Twitter to build community. There is little doubt that librarianship is committed to diversity as a core value. Similarly, there is little doubt that librarians use social media to stay connected with each other, learn from each other, and stay up-to-date on the trends and issues facing librarianship. By providing clarity to librarians' understanding of diversity and intellectual freedom as core values, this project will add context and nuance to core debates within the profession. 


\section{References}

ALA Council rescinds "Meeting rooms: An interpretation of The Library Bill of Rights." (2018, August 16). American Libraries. Retrieved form https://americanlibrariesmagazine.org/blogs/the-scoop/ala-councilrescinds-meeting-rooms-interpretation-library-bill-rights/

Alabi, J. (2015). "This actually happened": An analysis of librarians' responses to a survey about racial microaggressions. Journal of Library Administration, $55,179-191$.

Almeida, N. (2018). Interrogating the collective: \#Critlib and the problem of community. In K. P. Nicholson \& M. Seale (Eds.), The politics of theory and the practice of critical librarianship. Sacramento, CA: Library Juice Press.

American Library Association. (1996). Library bill of rights. Retrieved from http://www.ala.org/advocacy/intfreedom/librarybill

American Library Association. (2008). Code of ethics of the American Library Association. Retrieved from http://www.ala.org/advocacy/sites/ala.org.advocacy/files/content/proethics /codeofethics/Code $\% 20$ of\%20Ethics\%20of\%20the\%20American\%20Libr ary\%20Association.pdf

Bird, G. (n.d.). Open letter to CFLA Board. Change.org. Retrieved from https://www.change.org/p/canadian-federation-of-library-associationsopen-letter-to-cflaboard?recruiter=1011094056\&utm_source=share_petition\&utm_medium $=$ twitter\&utm_campaign=psf_combo_share_initial\&recruited_by_id $=3 \mathrm{bd}$ 93d70-f44e-11e9-95ca-f12c0e45295d\&share_bandit_exp=initial18738314-en-CA\&share_bandit_var=v0

CFLA-FCAB. (2019, Octobe 23). CFLA-FCAB upholds intellectual freedom [web log post]. Retrieved from http://cfla-fcab.ca/en/news/cfla-fcab-upholds-intellectual-freedom

Coombs, P.E., \& Rhinesmith, C. (2018). Edge Perspectives in online scholarly communities: A network analysis of \#critlib. Proceedings of the $81^{\text {st }}$ Annual Meeting of the Association for Information Science and Technology, 55, 86-93.

Dresang, E. T. (2006). Intellectual freedom and libraries: Complexity and change in the Twenty-first-century digital environment. Library Quarterly, 76(2), 169-192. 
Elmborg, J. (2016). Tending the garden of learning: Lifelong learning as core library value. Library Trends, 64, 533-555.

Figueroa, M. (2018, Feb. 6). Leaders of change share a vision for the future at midwinter diversity \& equity session. Retrieved from http://www.ala.org/news/member-news/2018/02/leaders-change-sharevision-future-midwinter-diversity-equity-session

Gibson, A. N., Chancellor, R. L., Cooke, N. A., Dahlen, S. P., \& Lee, S. A. (2017). Libraries on the frontlines: Neutrality and social justice. Equality, Diversity and Inclusion: An International Journal, 36, 751-766. doi: 10.1108/EDI-11-2016-0100

Gruzd, A., Takhteyev, Y., \& Wellman, B. (2011). Imagining Twitter as an imagined community. American Behavioral Scientist, 55(10), 1294-1318. doi: $10.1177 / 0002764211409378$

Hamilton, L., \& Corbett-Whittier, C. (2013). Research methods in education: Using case study in education research. London: SAGE Publications. doi: $10.4135 / 9781473913851$

krisjoseph. (2019, November 8). Open letter from the York University Faculty Association's Librarians and Archivists to the Toronto Public Library [web log post]. Retrieved from https://krisjoseph.ca/2019/11/08/yufa-letter-to-tpl/

Leung, C. (2019). Stop hate speech from being spread at the Toronto Public Library. Change.org.

Retrieved from https://www.change.org/p/toronto-public-library-requestfor-tpl-to-cancel-rental-booking-for-transphobic-event-at-palmerstonlibrary?recruiter=958259070\&utm_source=share_petition\&utm_medium= copylink\&utm_campaign=share_petition

LeRue, J. (2018, July 10). Library meeting rooms for all. Intellectual Freedom Blog. Retrieved from https://www.oif.ala.org/oif/?p=14997\#timeline

Mathuews, K. (2016). Moving beyond diversity to social justice: A call to action for academic libraries. Progressive Librarian, 44. Retrieved from http://www.progressivelibrariansguild.org/PL_Jnl/contents44.shtml

McLaughlin, Z. (2018, November/December). Getting advice. American Libraries, 57. "Meghan Murphy: Canadian feminist's trans talk sparks uproar. (2019, October 20). BBC News.

Retrieved from https://www.bbc.com/news/world-us-canada-50214341 
Mills, A. J., Durepos, G., \& Wiebe, E. (2010). Encyclopedia of case study research. Thousand Oaks, CA: SAGE Publications. doi: $10.4135 / 9781412957397$.

Moorhead, P. (2019, March 7). Demonstrating commitment to diversity and inclusion. Forbes. Retrieved from https://www.forbes.com/sites/patrickmoorhead/2019/03/07/hpdemonstrating-commitment-to-diversity-and-inclusion/\#5db651c4f855

Rawlinson, K. (2019, February 1). Trigger warnings OK but no-platforming may be illegal, universities warned. The Guardian. Retrieved from https://www.theguardian.com/education/2019/feb/02/government-tellsuniversities-to-protect-free-speech-on-campus

Saxton, G. D., Niyirora, J. N., Guo, C., \& Waters, R. D. (2015). \#AdvocatingForChange: The strategic use of hashtags in social media advocacy. Advances in Social Work, 16, 154-169.

Schlesselman-Tarango, G. (2016). The legacy of Lady Bountiful: White women in the library. Library Trends, 64, 667-686. doi: 10.1353/lib.2016.0015

Selby, M. (2012). Librarians as leaders. Feliciter, 58, 37-38.

Shiri, A. \& Rathi, D. (2013). Twitter content categorisation: A public library perspective. Journal of Information \& Knowledge Management, 12(4), 1350035 .

The Black Caucus of the American Library Association. (2018). Our history. Retrieved from https://www.bcala.org/our-history/

Toronto Public Library Workers Union. (n.d.). Letter to city librarian re: Palmerston Library room Booking [web log]. Retrieved from https://local4948.org/

Winsa, P. (2019, October, 29). Protestors gather outside public library as controversial feminist Meghan Murphy lectures to packed room. The Star. Retrieved from https://www.thestar.com/news/gta/2019/10/29/protestorsgather-outside-public-library-as-controversial-feminist-meghan-murphylectures-to-packed-room.html 